\title{
(Un)equal Treatment? Elderly care and disability services for people with dementia in Finland ${ }^{1}$
}

\section{Hanna-Kaisa Hoppania}

University of Tampere

\author{
Anna Mäki-Petäjä-Leinonen \\ University of Eastern Finland
}

\section{Henna Nikumaa}

University of Helsinki

\begin{abstract}
The rights of older people to care have become a major political and legal issue with the ageing populations of many European and OECD countries. Finland is an interesting case in this respect because, in 2013, extensive new legislation was passed there concerning the rights of the older population to access care services. This article describes the context in which the 'Act on Supporting the Functional Capacity of the Older Population and on Social and Health Services for Older Persons' (980/2012 Elderly Care Act) was drafted, and what the Act aims to accomplish. It argues that while the Act is ambitious and symbolically significant, it remains unsatisfactory in practice. This is the case especially for people with dementia, who end up being disadvantaged. We compare the Elderly Care Act with other relevant legislation, in particular legislation pertaining to disability services, and estimate the significance of the law from the perspective of older people with dementia. We also discuss the situation in Finland in relation to the global situation of people with dementia as the UN Convention on the Rights of Persons with Disabilities was recently ratified in Finland. We show that disability legislation, rather than elderly care legislation, should be the framework through which the right to services should be secured for people with dementia.
\end{abstract}

Keywords: dementia; equality; discrimination; disability services; Elderly Care Act, UN Convention on the Rights of Persons with Disabilities; old age

1 The final version of this article has been publised in the European Journal of Social Security EJSS 19 (3), 225-241. When citing, please refer to the published version. 


\section{Introduction}

The rights of older people to care services have become a major political and legal issue with the ageing populations of many European and OECD countries (e.g. Kelly and Innes 2013; OECD 2013). In Finland, this situation was acknowledged and addressed recently through new legislation, namely the Act on Supporting the Functional Capacity of the Ageing Population and on Social and Health Care Services for Older People (980/2012, henceforth the Elderly Care Act), which was passed in 2013. The legislation aimed to develop the elderly care system with an emphasis on preventative care, so that the need for long-term care would be postponed and the cost of services would be contained. Furthermore, it aimed to secure adequate care for older people in need (Hoppania 2015: 139-140). However, as the Finnish Constitution (731/1999) and other acts concerning social services already set out the entitlement to care in old age, this led to the question: why was a specific new Act needed? Did the Elderly Care Act improve the position of older people, and what other laws are relevant to their situation?

This article discusses the Finnish situation as a cautionary example of how legal developments that are typically framed as reforms that improve service provision might in practice not help those in need at all, and even entail or serve to hide the deterioration of rights for services. The number of older people is growing, and this presents legal and political challenges for many countries; societies have to somehow respond to the growing needs for services of this group, if and when their families cannot supply all the care that is needed. Furthermore, for the purposes of this article, it is crucial to note that dementia is a relatively common condition among older people, and Alzheimer's Disease (the most common cause of dementia) is a leading cause of disability for older people (Burns and Iliffe 2009; Jönsson and Wimo 2009; Li et al. 2015).

In this article we examine the position of older people who require care services in Finland. We focus on older people with dementia, because currently, as shown below, their status as disabled and/or as older people makes them particularly vulnerable to unjust treatment. This article attempts to demonstrate that at the heart of the question of the (un)equal treatment of older people with dementia is the way in which older people and disabled people are defined, classified and treated in law and by the social services. Dementia is not usually recognised as a disability in policy or in practice (Mental Health Foundation 2015: 6). Distinctions and boundaries in status, definitions of adequacy and needs that are created in legislation concerning services, and in their application and interpretation, might entail unequal and discriminatory practices, as illustrated by the situation in 
Finland. To contextualise the political situation and the service structure in Finland, we explain what happened with the enactment of the Elderly Care Act and compare it with legislation concerning disability. The analysis provides important insights into how the rights of people with dementia might be improved and how the quality of their services is at risk of deteriorating. Previous research has highlighted the need for such knowledge and studies, and the role of research has been highlighted in the ongoing and future legislative and organisational developments in the area of care (Taghizadeh, Larsson and Österholm 2014). We focus on the situation of older people with dementia because, we argue, they are a group of older people who should clearly be treated as disabled. In spring 2016, Finland also ratified the UN Convention on the Rights of Persons with Disabilities (13 December 2006, later UN Disability Convention), which makes the case timely and relevant from the perspective of the international recognition of disability rights.

The article is structured as follows. First, we describe the social and political context in which the Elderly Care Act came about. We then analyse the contents of the legislation and present a critical account of why the Act is unsatisfactory. To make this critique more concrete, we then move on to examining the Elderly Care Act from the perspective of a person with dementia, as they are the largest group of older people who need continuous care and different social and health care services (Eloniemi-Sulkava, Sormunen and Topo 2008: 9, 11). We scrutinise elderly care and disability legislation and services, and demonstrate that a better way of securing care for people with dementia is to apply disability legislation to them equally. This means treating them in the same way as people in other illness and disability groups. Finally, we discuss the significance of the Finnish situation in the wider context of disability rights and older people's rights to services. We consider the political and economic challenges of treating older people with dementia equally in the field of disability and social welfare legislation.

Throughout our analysis we draw from previous research and utilise data from our own wider research projects in this field. The sources include previously unpublished material from Hoppania's study of the policy process for the Elderly Care Act (Hoppania 2015), in particular policy documents and comments on the draft versions of the Elderly Care Act. We also include material and case examples from Nikumaa's Master's Degree thesis (Nikumaa 2010) which have not previously been published in English. Thus we provide a critical reading of the new legislation in the context of wider literature and studies concerning the implementation of existing policies. In our previous research, we have studied this area from different perspectives: Hoppania has studied elderly care legislation, politics and service provision; Mäki-Petäjä-Leinonen has focused on the 
Elder law, combining jurisprudence with social and medical sciences; and Nikumaa's research concentrates on equal rights of people with dementia and supporting their legal capacity.

\section{Development of the care and legislation for older people}

The latest research on social policy in Finland suggests that, in recent years, the traditionally strong Nordic welfare state structures have been significantly reshaped, and social provision regarding the care of older people in particular is developing according to a (neo)liberal agenda (Anttonen and Häikiö 2011; Hoppania 2015; Karsio and Anttonen 2013). However, many features, ideals and practices of socialised care still characterise the law and governance of care services. Finnish social policy was largely developed in the decades after the Second World War, actively building on the Nordic welfare state model, in which society is committed to offering social care services to all citizens on a universal basis. The ethos was that everyone has the right to state-provided services, irrespective of their employment status, and individuals' dependency on their families was minimal. This had a decommodifying impact, as it rendered the well-being of individuals independent of market forces (Borchorst and Siim 2002: 91; Esping-Andersen 1999: 43-47). At the same time, the model aimed to support gender equality by reducing women's domestic and care work burden. In addition, the legal obligation of grown-up children to provide for their ageing parents was also annulled in the 1970s (Anttonen and Sipilä 2000: 66; 109).

Older people in Finland can expect the public authorities to provide for them during old age when their need for care increases. However, the precise level of services that an older person is entitled to is unclear. For instance, the role that client fees play in public (sometimes outsourced) elderly care services, in particular in relation to diverse forms of housing services, has not been defined clearly in law. In contrast, in the field of child care, the entitlement to day care and income related service charges are clearly defined. Furthermore, while institutional care in care homes/nursing homes was the dominant form of publicly-funded care for older people in the heyday of the welfare state in the late $1980 \mathrm{~s}$, since the $1990 \mathrm{~s}$, these services have been subject to austerity measures. In elderly care, the number of places in institutional care homes fell approximately by 20 per cent, and the number of households that received home help dropped by 40 per cent during the 1990s (Kiander 2001: 94). Today, home care, that is care services provided by the municipality in the older person's home, are the new ideal arrangement. Sometimes NGOs or private companies provide these (outsourced) services, but even in these cases the municipality typically pays most of the costs, for example through a voucher system. However, redistribution of public resources for home care has been weak. Examining elderly care services from 1989 to 2002, Vaarama and Noro (2005) 
noticed that home care (supplied by the municipality) was in continuous decline. They suggest that this means that responsibility for care has been reallocated to the elderly person's family and relatives. The service structure reform has thus meant a transition towards more lightly staffed care facilities and from municipal services towards supporting family care (Vaarama and Noro 2005). These trends have, more recently, been confirmed by Karsio and Anttonen (2013).

Concurrently, long-term institutional care has been reduced and the clients of elderly care services have increasingly moved to serviced apartments, that is, supported housing with care services, which is often in the private market (even if it is subsidised by the municipality). Indeed, the marketisation of the sector has been strong, especially in intensive service housing, which is a new form of 24-hour residential care, typically for older people, and is increasingly replacing the old municipal care homes (Hoppania 2015: 76; 81). While the service housing system aims for more home-like living than the old long-term institutional care with round-the-clock care, in practice it is used by the municipalities to transfer more of the responsibility for the costs of care to the service users themselves, with little change in their living conditions (ibid.: 156).

Overall, during the last two decades the universalist ideals of the welfare state have increasingly been subsumed by consumerism and neoliberal trends (Hoppania 2015; Karsio and Anttonen 2013; Vaarama and Noro 2005). Thus, when the decision to start drafting the Elderly Care Act was taken in 2009, the elderly care system was going through structural changes with an emphasis on outpatient care, marketisation and family responsibility. The practices concerning the level of client fees, and the accessibility and level of services older persons could expect to receive, varied regionally. Furthermore, the economic downturn, together with the realities of worsening demographic dependency ratios, made the economic resources for elderly care services very tight. The final impetus to preparing the legislation, however, came mainly from public demand for more legally secure and higher quality care for older people.

A wide-scale public debate erupted after official reports and media scandals had revealed deficiencies and the low quality of elderly care in many long-term institutional care units and in intensive service housing. Approximately half of the residents of these units were admitted with dementia (Huttunen et al. 2011: 20). Deficiencies in nutrition, inadequate adult changing, the use of restraints, a lack of outdoor activities, over-medication allegedly due to staff shortages, and other issues, were highlighted in the debate which forced the topic onto the political agenda. It was 
widely recognised that the issues that had been raised were a genuine problem which needed to be addressed. The idea of and demand for better regulation in the form of new legislation were presented as part of the solution to the problem with elderly care services that the then Minister of Health and Social Services described as the biggest challenge facing Finnish society (PTK 84/2009).

As the issue gained visibility and attention in the media and in Parliament (an interpellation was filed over the issue by the parliamentary opposition), the air was filled with promise and high expectations. Consequently the preparatory process was thorough and an extensive range of interest groups and experts were consulted throughout the various preparatory stages in the Ministry of Social Affairs and Health, and in the final phase within the Parliament. Finally, at the end of 2012 the bill was passed.

\section{The Elderly Care Act: what did it change?}

The Elderly Care Act came into force on 1 July 2013. The central objective of the Act is to support the wellbeing, health, functional capacity and independent living of the older population and to improve their access to high-quality social and health care services. The term 'older population' in the Act refers to that segment of the population which has reached the eligible age for a retirement (old-age) pension, and 'older person' means a person whose functional capacity is impaired because of old age or due to degeneration related to old age $(\S 3)$. There is no age limit at which people become eligible for rights under the Act.

The Act describes the care chain for older persons and contains provisions concerning advice services, the mapping of service needs, the right to have a service plan and decisions on the provision of social services. It also contains provisions on the quality of services. However, other legislation which applies to the population as a whole contains provisions that are very similar to those in the new Act. Thus, one can question whether the Act brought any additional value to the care services for older persons. Did it, in fact, change anything?

There are some new provisions in the Elderly Care Act that are not to be found in any other legislation that applied at the time. First, the Act addresses the responsibility of local authorities to establish a council for older people to guarantee the older population's opportunity to participate in, and exert influence over, local decision-making $(§ 11)$. Secondly, it established a timeline for the provision of social services. According to the Act, an older person has the right to access social 
services, other than urgent services, provided to them without unnecessary delay, and at the latest three months after the taking of the decision $(\S 18)$. Thirdly, according to the Act, older married and cohabiting couples must be offered the opportunity of cohabitation (§14). Finally, it includes a provision on the reporting of an older person's service needs. According to the Elderly Care Act, if a health or social care professional has been informed that an older person is in need of social or health care services, they must, confidentiality provisions notwithstanding, notify the authority responsible for municipal social welfare $(\S 25)$.

Despite these new provisions in the Elderly Care Act, other recent regulatory reforms in Finland have quickly changed the situation so that other legislation contains essentially the same provisions as the Elderly Care Act. Namely, the new Social Welfare Act (1301/2014), which came into force on April 2015, has provisions first, on the above mentioned right to obtain social services at the latest three months after the decision $(\S 45)$; secondly, on the responsibility of social and health care professionals to notify relevant authorities when they become aware of a person in need of services (§35); and finally, on married and cohabiting couples’ right to cohabit (§30). Furthermore, the Local Government Act (410/2015) was revised in 2015 and now contains a provision concerning the council for older people (§27). Thus, it is apparent that the Elderly Care Act does not in fact (anymore) have concrete provisions that would be particularly important for older persons. Other legislation guarantees the same rights for all.

There are further reasons why the significance of the Elderly Care Act can be questioned. First, arguably some of the most crucial issues were not addressed in the legislation. For example, the number of personnel in care units was left unregulated, meaning that there are no sanctions for understaffing, although complaints were repeatedly made about staff shortages during the drafting of the Elderly Care Act (Hoppania 2015: 91-93; 140-147). The issue of informal family care, too, was left out of the Act. Whilst in principle the promises of the Elderly Care Act also apply to informal family care situations, no concrete measures or policies to support and allow for betterintegrated elderly care within families were introduced in the Act (ibid.: 157). This is somewhat peculiar, as in Finland the informal care of dependent adults is an important form of care work and saves an estimated EUR 2.8 billion annually in service expenditure (Kehusmaa 2014) - a significant amount, as the total expenditure for services for old people and disabled people is EUR 5.2 billion (The Ministry of Social Affairs and Health 2016a). There is legislation detailing benefits and support services for informal care (Act on Support for Informal Care, 937/2005), but it is widely regarded as unsatisfactory. For example, the informal caregiver's allowance is modest, and is 
granted arbitrarily at the discretion of the municipality. An example from our interviews (Nikumaa 2010) concerning people with dementia as clients of the social security system, illustrates this situation:

'I work as a memory nurse in several municipalities so I know how unequal the treatment that people with dementia and their carers get, is. The criteria for granting support to informal caregivers was very diverse, even random.' (Nurse with 22 years of experience of working in social services with people with dementia.)

There is also the Family Care Act (263/2015) but this has traditionally been applied only when a child or a juvenile needs care. The law concerning informal and family care is currently being reformed with the aim of developing home care for older people and enhancing informal care for all age groups (The Ministry of Social Affairs and Health 2016b).

Secondly, the practical meaning of many of the provisions introduced in the Elderly Care Act remains debatable. For example, the opportunity for couples to cohabit seems only to be interpreted as a recommendation. In response to frequently asked questions concerning the interpretation of the law in practical situations, the Ministry of Social Affairs and Health, on their website, explains that '[the Elderly Care Act] does not grant a subjective right to live together' (The Ministry of Social Affairs and Health 2014). A subjective right in the Finnish context means a strong entitlement to a service, independent of municipal resources. These types of rights are granted, for example, in the Children's Day Care Act (36/1973) and in the Disability Services Act (380/1987) (Tuori and Kotkas 2016.).

Likewise, the Ministry explains that the principles of long-term care laid out in the Elderly Care Act (§14) should be taken into consideration in the planning and implementation of services. However, the advice given on how to apply the law allows municipalities, for example, to refuse to pay the allowance for informal care (The Ministry of Social Affairs and Health 2014), even if this compromises the permanence of the long-term arrangements of an older person that the law is, in principle, meant to secure. Indeed, the Elderly Care Act is contradictory in that it undermines its own promises when, for example, in $\S 14$ it states that '[1]ocal authorities must ensure the permanence of long-term care arrangements for an older person', but then allows the changing of arrangements not only based on the person's changed service needs, but also for another 
'particularly important reason'. In practice, this could mean that the municipality could stop paying the informal care allowance simply by referring to a difficult economic situation.

The significance of some of the more strictly binding Articles, too, remains unclear. For example, the obligation for local authorities to establish an advisory council for older people has been criticised and specification has been demanded (Hoppania 2015: 129). While the obligation to establish such a council is strict and binding, there are no provisions detailing what the role of the council in the municipality and in the decision-making processes concerning the provision of services should be. It has been suggested that the statements of the councils for older people will have no significant steering influence as the municipal office-holders or boards can simply record the statements as received, without any obligation on the office-holders and municipal political organs to react in some way (see Hoppania 2015: 129-130). The weak binding force and lack of specification of many of the provisions in the law thus undermines the seemingly progressive law.

Reservations and worries like these also apply to many of the general provisions of the Act. There are, for example, Articles demanding 'adequate resources', but no standards are given as to how adequacy is defined. The Act lacks concrete provisions establishing subjective rights to care services. Instead, many provisions are written in the form of principles. According to the general principles concerning how to respond to service needs, the law states that 'local authorities must provide older persons with social and health care services of a high quality that are timely and adequate to their needs. The services must be provided so as to "support the wellbeing, health, functional capacity, independent living and inclusion of older persons. In order to prevent other service needs, attention must be paid in particular to services promoting rehabilitation and services provided in the old person's own home' (§13, emphasis added). Furthermore, according to the principles for the provision of long-term care, 'social and health care services securing long-term care must be provided so that the older person can feel that they are living a safe, meaningful and dignified life and can maintain social contacts and participate in meaningful activities promoting and maintaining their wellbeing, health and functional capacity' (§14, emphasis added). Thus, as many provisions in the Elderly Care Act are written in the form of principles, there is a risk that such provisions remain ineffectual in practice, or function simply as symbolic recommendations (Mäki-Petäjä-Leinonen, Hoppania and Nikumaa 2015).

In any case, the Finnish Elderly Care Act merely describes the ideal procedure for providing services, the realisation of which is not supported by a commitment to redistribution or the use of 
sanctions. This can be considered a serious failing of the Act, as the law was presented as a solution to a situation that was, arguably, caused not by a lack of regulation in the first place but because existing laws and recommendations were not adequately followed (Hoppania 2015: 129; cf. Banerjee, 2013). The problem of high ideals and symbolic recognition but little practical support in the field of care is not only a Finnish phenomenon. Similar critiques of toothless reforms have, for instance, been presented regarding government reforms for supporting carers in the UK (Herring 2013).

How, then, does other legislation regulate social and health care services for older people in Finland? Because many older people are also disabled, for example, if they have a degenerative neurological illness such as Alzheimer's Disease, we turn next to examining and comparing elderly care services and disability services, and their role in relation to social services in general. This comparison reveals alternative possibilities for improving the situation of older people with dementia.

\section{Elderly care services $v s$. disability services}

In Finland the municipality can provide social and health care services for older people based on different laws. The principle is to provide services based on general legislation, such as the Social Welfare Act (1301/2014) and according to a person's need, not according to the age of the person. Hence, the provision of services for people with disabilities is primarily based on the Social Welfare Act. The legislation on disability services is secondary and is only applied in cases where a person has not received sufficient services or benefits under some other legislation - such as sufficient transport services under the Social Welfare Act.

The Disability Services Act (380/1987) supports disabled persons' living conditions to enable them to live and work as equal members of society. It further aims to prevent and remove disadvantages and obstacles caused by disability. The Disability Services Act guarantees certain services and forms of support, such as personal assistance or transport services (18 journeys per month), for a person who meets the law's definition of a severely disabled person. These guaranteed forms of support are considered to be subjective rights, and, as such, they cannot be conditional on the financial status of the municipality. This is the main reason why the Disability Services Act provides a better legal guarantee for a person in need of services than the Social Welfare Act. 
Yet, the definition of severe disability is considered unclear in practice (Nikumaa 2010). There are different criteria of severe disability in the Disability Services Act and (Disability Services) Decree - different criteria for different services. For instance, these vary between clauses concerning the services of personal assistance (Act $\S 8 \mathrm{c}$ ), day activity services (Act $\S 8 \mathrm{~b}$ ) or transport services (Decree §5). This, in itself, causes confusion. In practice, these definitions of severe disability, are traditionally interpreted in terms of physical disability. This puts those, who are physically in good condition but are cognitively challenged, in unfavourable position. For instance, according to the Supreme Administrative Court's decisions 2005:1399 and 2005:1400, a person with dementia was not defined as severely disabled, even though there are no such definitions of severe disability in law that should led to people with cognitive disabilities being excluded.

The Elderly Care Act, on the other hand, is meant to improve the possibilities of older people receiving the care services they need.. In its definitions, the Act defines the 'older person' (to whom the decrees apply) as someone 'whose physical, cognitive, mental or social functional capacity is impaired due to illnesses or injuries that have begun, increased or worsened with high age or due to degeneration related to high age' (Elderly Care Act, §3). This definition distinguishes between needs that are related to age, and other kinds of needs by defining and classifying people as older people, people disabled at a young age, people disabled in old age, people with dementia and so on, and granting these groups different rights or services. In practice, the need for help, assistance, care and services can be very similar, or as grave, for people who are differently classified.

Already during the drafting of the Elderly Care Act, there were concerns voiced that older people with disabilities are treated differently from other disabled people. In a statement on a draft version of the legislation, one NGO claimed, that many municipalities applied disability legislation arbitrarily: severely disabled older people were sometimes transferred from falling under the remit of the Disability Services Act to the Social Welfare Act, after which some of the necessary transportation and other services were denied them with reference to the strict income and property conditions in the Social Welfare Act (Hoppania 2015 data). The NGO worried that the Elderly Care Act would create a gateway for age discrimination, as the new law provide a legal basis for practices under which the Disability Services Act was no longer applied to older severely disabled people (ibid.). This interpretation would leave many older people with disabilities without services that they could not afford to pay for privately. 
The NGOs were concerned that the Elderly Care Act might create more possibilities for unfair practices. They argued that to improve the situation, the Disability Services Act should be applied equally to all older people who satisfy the definition of a severely disabled person, and criticised the Elderly Care Act for not making it clear how these different pieces of legislation were to be applied. The NGOs thought the problem lay with the legal definition of an older person (quoted above) which could be used to simply leave elderly persons whose functional capacity is impaired in old age without access to disability services. They also noted that, in practice, the interpretation and application of the Disability Services Act and the Social Welfare Act were already inconsistent.

These concerns suggest that at worst, the Elderly Care Act might cause new billing practices for services, and new application and interpretation problems for older, disabled people. Although existing disability legislation does not exclude any illness or disability group and does not set any age limits for clients, in practice the line drawn between care needs and services for disabled and elderly people is not clear. The application of the law varies, and this is particularly evident in the case of people with dementia. The fact that sometimes very similar needs result in access to very different services because of the age or illness of a client is discriminatory, and is clearly a significant ethical and human rights issue. Indeed, according to the Constitution of Finland (731/1999), everyone is equal before the law. No one shall, without an acceptable reason, be treated differently from other persons on the grounds of sex, age, origin, language, religion, conviction, opinion, health, disability or other reason that concerns his or her person (§6, Equality, emphasis added).

While inequalities in care services might be related to these other grounds, we focus in this article on older people with dementia, and argue that, for this group at least, it is clear that, to secure their equal treatment, they should be treated as disabled. This is a current and globally relevant argument as the UN Disability Convention has finally been ratified in Finland and the application and interpretation of its mandates is timely. Furthermore, the international NGOs in the field of dementia have also called for the recognition of dementia as a disability (DAI 2016; Mental Health Foundation 2015). We focus next on the challenges raised by this interpretation by discussing the Finnish situation and its connection to the global situation.

\section{People with dementia as people with a disability?}

People with dementia form a significant segment of the older population, and as discussed above, their care needs are currently not being met adequately. Furthermore, their condition weakens their 
legal capacity as the illness progresses. We thus discuss their position as regards services, and compare their rights as older people, or when they are defined as disabled.

The population in Finland, as in many countries of the Global North, is ageing, and the most frequent long-term illnesses among older people are neurological degenerative illnesses such as Alzheimer's Disease (Ferri et al. 2005; Fratiglioni et al. 2000; Gardner, Valcour and Yaffe 2013). These illnesses cause dementia as they progress through the weakening of memory and the decreasing ability to process facts. It has been estimated that 35.6 million people lived with dementia worldwide in 2010 (Prince et al. 2013). It is expected that this number will double by the year 2030 and more than triple by 2050, bringing the estimated total to some 115 million worldwide (Alzheimer's Disease International and World Health Organisation 2012). The costs of caring for people with dementia have an enormous global economic impact, affecting the health care and social service systems of many countries. The total estimated worldwide cost of dementia was US\$ 604 billion in 2010, out of which approximately 70 per cent was concentrated in Western Europe and North America (Wimo et al. 2013). In Finland, the number of people with dementia is estimated to be 193,000 out of the total population of 5.4 million. Each year, 14,500 people become afflicted with a degenerative neurological illness such as Alzheimer's Disease and related disorders (Viramo and Sulkava 2015).

The current practices of interpretation and the application of social service and disability legislation in Finland often put people with dementia in a worse position compared to other groups with different diseases or disabilities. A person with dementia can be physically in good condition and, for example, may in principle be able to walk to the closest bus stop. However, the disease will soon become an obstacle in everyday life, and the person with dementia may no longer be able to recognise at which stop they should get off the bus, or may be unable to buy a ticket. Still, these cognitive challenges are not usually regarded as a disability that would justify the entitlement to disability services for people with dementia (Mäki-Petäjä-Leinonen 2013; Nikumaa; 2013, 2015a and 2015b). In our previous study (Nikumaa 2010), the social and health care professionals we interviewed reflected on this situation:

'Based on the Social Welfare Act, no more than 8 transports per month are granted [for people with dementia] and [they] are satisfied with that. The truth is, however, that this is not enough. But there is a decision about [this limit] in the municipality at 
a level of principle. People with dementia are not even told about the possibility of applying for transport services based on the Disability Services Act.' (Memory nurse in a hospital who had worked with people with dementia for five years).

'It is more difficult for persons with dementia than for others to get transport services [according to the Disability Services Act]. They only look at physical capacities.' (Service coordinator in an association of people with dementia with 15 years of experience of working with people with dementia).

'Many patients with dementia would be greatly helped by transport services [according to Disability Services Act], for example, but in our municipality they seldom get them. It is said that if they started to grant [these transport services to patients with dementia], there would not be enough money. There are so many patients with dementia.' (Social worker in a health centre, who had worked with people with dementia for four years).

According to Article 1 of the UN Disability Convention, 'persons with disabilities include those who have long-term physical, mental, intellectual or sensory impairments which, in interaction with various barriers, may hinder their full and effective participation in society on an equal basis with others'. As progressive neurological diseases weaken the person's physical, psychological and social capacity, it seems clear that the Convention must apply to people with dementia (see also Harding 2017). The UN Convention uses a social model of disability (Mental Health Foundation 2015), which is based on an evolving conception of disability and does not make any distinctions between the causes or forms of disabilities. Thus, it does not exclude any age, illness or disability groups. On the contrary, it emphasises equality.

Finland signed the UN Disability Convention in 2007 but did not ratify the Convention until spring 2016. The ratification was postponed because Finnish legislation did not adequately reflect the Articles of the Convention. Reforms were needed, for example, to update the legislation concerning people with intellectual disabilities. New provisions concerning restrictive measures were set out in the Act on Special Care for People with Intellectual Disabilities (519/1977, henceforth the Intellectual Disability Act) so that the situation concerning restrictions to freedom would meet the requirements of the Convention. However, the rights of people with dementia were ignored as the 
Intellectual Disability Act does not usually apply to people with dementia. From the perspective of equality, it would have been vital to update the legislation from the perspective of all disability groups in Finland before the UN Disability Convention was ratified. In essence, this means that, for example, the practices involved in restricting the freedom of people with dementia in Finland are contrary to the UN Convention (Mäki-Petäjä-Leinonen 2017). ${ }^{1}$

There is also work in progress to reform the Finnish Disability Services Act. The aim of the reform is to combine the Disability Services Act and the Intellectual Disability Act to improve the equality of disabled persons. The planned reform has received a substantial amount of criticism. Indeed, the proposed changes are worrying. In May 2017 the Ministry of Social Affairs and Health published a draft for an act on special services provided on the basis of disability. The draft suggests a limitation according to which the new law would not apply to an older person as defined in the above mentioned Elderly Care Act $\S 3$. From the perspective of equality, this kind of age-related limitation is problematic. It is vague and causes confusion especially for people with dementia as dementing illnesses are not part of normal ageing and they also occur in younger age groups (Ridha and Josephs 2006).

Interestingly, in its justification the draft act states that a categorical age limit would not be set (Ministry of Social Affairs and Health 2017). However, at the same time there is a reference to the Government's proposal for the Elderly Care Act in which it is stated that "normally people's functional capacity weakens and the need for services increases significantly around the age 80-85” (HE 160/2012). It is likely that this reference would direct the interpretation and application of the law so that the age limit would in fact be set around 80-85.

The justifications of the draft in effect put people in unequal position also within same illness and disability groups. As an example, the justification discusses a situation in which the functional capacity of a 50 year old is impaired due to a reason that is typical for those who are over 80 . The draft act states that the person could not be excluded from the remit of the law because of this

$1{ }^{1}$ One solution in Finland could have been the preparation of a new law on autonomy. In fact, the previous government started preparing new legislation on strengthening the autonomy of patients and clients of social and health care services and on the use of restrictive measures ('Autonomy Act') that would have established new provisions concerning restraint and confinement practices in social and health care. Currently, many restrictive practices are used in long-term care facilities, such as tying a person down to a chair and locking the doors, but these practices are unconstitutional. The basis of the restrictions on freedom should be set out clearly in legislation. However, this proposed bill lapsed at the end of the term of the previous government. Had the law been enacted, it would have applied to approximately 23,000 people with dementia and to about 1,000-2,000 mentally disabled people. The preparation of the Autonomy Act is expected to continue in 2017. 
reason. In other words, someone of working age who falls ill with Alzheimer's disease, would have a right to disability services, but an 80 year old would be excluded from these services.

Thus, we argue, that in fact the draft act facilitates the discrimination of different forms of disabilities and violates the principle of equality: it is age discrimination and can also be considered discriminatory for different disability and illness groups. This kind of regulatory framework would be against the principle of equality laid out both in the Finnish Constitution and in the UN Convention, and it would also be against the Finnish Non-Discrimination Act (1325/2014, §8).

The draft act also states that in those situations where older person is left outside the application of the Disability Service Act, their rights are provided by the Elderly Care Act and Social Welfare Act. Unfortunately, those Acts do not, as discussed above, guarantee the level of services that would meet the needs of people with dementia to the same extent as the Disability Services Act does. In addition to the case of transport services discussed above, the Social Welfare Act and the Elderly Care Act do not, for example, include a right to specialised services such as personal assistance. Thus, we have a situation where one neurological disability group, namely people with dementia, are discriminated against. This is also evident in the following examples from the previous study (Nikumaa 2010) concerning people with dementia as clients of the social security system. Here, the people with dementia and their carers were asked about equality when applying for social security benefits:

'The thing is that sometimes I feel like if you had any other disease than my Alzheimer's you would get the services and other stuff you need. That is just the way it is' (70-year-old woman with Alzheimer's Disease, living alone in her own house).

'I got to go to that course only when I got those other illnesses diagnosed. At first, they said we don't arrange that for you' (76-year-old woman with Alzheimer's Disease, living alone in a service housing).

Additionally, social and health care professionals have witnessed the unequal treatment of people with dementia. Professionals making decisions about social security may be ignorant of the nature of dementing illnesses and their symptoms. They may also lack expertise in other specific areas and 
thus do not always understand what kind of help is needed. An example from the previous study (Nikumaa 2010), cited by the social and health care professional, exemplifies this situation:

'If we draw a comparison, say, with MS patients in our municipality, it is much easier for them to get to adaptation training courses, for example. Memory patients are rarely even offered the possibility to apply' (Public health nurse at a health centre who had worked with people with dementia for two years).

The situation in Finland is not unique. The importance of the (un)equal situation of people with dementia has also been emphasised by Alzheimer's Disease International (ADI) and Dementia Alliance International (DAI), who have called for a global recognition of dementia as an invisible disability (DAI 2016; see also Gilliard et al. 2005; Mittler 2015). In March 2015, at the opening address of the World Health Organisation's Ministerial Conference on Global Action Against Dementia, Dementia Alliance International asserted that the UN Disability Convention must include people living with dementia. According to Kate Swaffer, Co-chair of DAI:

\begin{abstract}
'People with dementia around the world are looking to ADI and national Alzheimer associations to ensure that the rights embodied in the Convention on the Rights of Persons with Disabilities include people with dementia. Only then can people with dementia be accorded the same rights as others living with disabilities, and the respect to make decisions about their own lives to the extent they are able'. ${ }^{2}$
\end{abstract}

\title{
Conclusions
}

As many nations around the globe are ageing, and the numbers of people with dementia are on the rise, there is momentum to demand and press for improved rights to services for this group. However, at the same time, austerity trends have translated into drastic cuts to various social services in many countries, of which Finland is just one example. It is, however, significant that, even in the context of a relatively strong welfare state and quite comprehensive and effective disability legislation, (older) people with dementia can remain in an unequal position and are discriminated against. The ongoing legal reforms create the possibility of improving existing laws and eliminate discriminatory practices. However, as discussed above, it seems that, instead, these reforms are being used to introduce new age- and illness-based distinctions and boundaries that do

$2{ }^{2}$ See ADI website, available at: http://www.alz.co.uk/news/un-international-day-of-persons-with-disabilitiesdementia-invisible-disability 
not help older people to receive better care and services, and can even worsen the position of older people with dementia. It is not an exaggeration to say that the Elderly Care Act is completely useless in this context. Indeed, the situation of older people with dementia shows that what is required is strong legislation that grants clear rights to services according to individual needs.

From the perspective of human rights, dignity and equality, we have stressed that there is no solid justification for denying older people with dementia the services they would receive based on the current disability legislation in Finland. Therefore, we argue that they should be legally considered as disabled. We argue for further research and international comparisons in this field, as knowledge of distinctions between older people and people with dementia and disability laws and other legislation is lacking. As the Finnish case shows, boundaries created in these laws and in the application of these laws may significantly affect the level and adequacy of services that are provided for people in need.

We also recognise that the dominant economic rationale of many of the social policies today makes it hard to argue for improved rights for services. In the European context, austerity trends prevail and the institutions of the welfare state have come under attack. The rise in the numbers of older people is the crux of the matter here. For example, in Finland, the number of disabled people (when people with dementia are not counted as belonging to this group) is at a completely different (i.e. lower) level compared to the number of all older people who require services. Hence the price tag of services provided for these two groups is very different leading to politicians being very willing to support the benefits of quite strictly defined groups of disabled people but very careful when it comes to the larger cohort of older people (Hoppania 2015, 139-140). The same dynamic seems to apply to the question of people with dementia. Were they to be considered disabled, the costs of their care would rise, and in the current political climate, this is not acceptable. Indeed, even existing rights and services for the more strictly defined disabled are now expected to be cut. Nevertheless, while support for the welfare state is still strong in Finland, and in many other countries, it is urgent to study the effects of the various service reforms to specific groups of older people, disabled, and beyond.

We would even claim that, precisely because of the threats to services that austerity politics and strict definitions of need-based services pose, it is more crucial than ever to argue for the equal application of the disability law in Finland as the UN Disability Convention has recently been 
ratified. It should be clearly stated what the position of people with dementia is, so that, when the disability legislation is reformed to reflect the UN Convention, we do not face the same kind of problems that the Elderly Care Act has produced, with its vague or merely symbolic provisions.

All countries grappling with the challenge of an ageing population face the question of how to provide services for growing groups, such as older people with dementia. When policy decisions on these issues are made, the definitions and boundaries drawn between older people and disabled people, or the classifications in terms of particular illnesses and conditions, are a crucial field in the legal and political struggle for equality (cf. Flacks 2012). The importance of these questions extends to family members and workers, too, and to the gendered economics of care work (cf. Stewart et al. 2011).

The Finnish case discussed in this article brings to the fore the kind of developments that austerity trends of cutting social welfare expenses can cause in law. It is a cautionary case in that it shows how even acquired and seemingly strong legal rights and services are in jeopardy in the ongoing welfare reforms that are typical throughout Europe. These reforms can be couched in terms that hide and conceal the actual deterioration of service provision. The current Finnish government, for instance, defends and frames the ongoing legal reforms in terms of structural reform to improve services, and claims that it is making services better available and more equal. The actual policy solutions that would directly detract from disability services are justified by abstract claims that 'those services that are needed' will be secured. However, as we have argued in this article, in Finland the disability legislation is actually the framework through which stronger rights for older people with dementia could be secured, and legislation such as the Elderly Care Act is not a way to improve the rights of anyone.

\section{Acknowledgements}

Hanna-Kaisa Hoppania has received funding for her research from the Alfred Kordelin Foundation and Mäki-Petäjä-Leinonen from the Ella and Georg Ehrnrooth Foundation

Thanks are due to Professor of Social Gerontology Antti Karisto and his team of doctoral students from Faculty of Social Sciences in University of Helsinki, as well as for postdoctoral researcher Linda Hart, for offering valuable suggestions for this paper. 


\section{References}

Alzheimer's Disease International and World Health Organisation (2012) Dementia. A Public Health Priority, UK: World Health Organisation.

Anttonen, A. and Häikiö, L. (2011) 'Care "going market”: Finnish elderly-care policies in transition', Nordic Journal of Social Research, 2, 70-90.

Anttonen, A. and Sipilä, J. (2000) Suomalaista sosiaalipolitiikkaa, Tampere: Vastapaino.

Banerjee, A. (2013) 'The regulatory trap: Reflections on the vicious cycle of regulation in Canadian residential care', in Meagher, G. and Szebehely, M. (eds.) Marketisation in Nordic Eldercare: A research report on legislation, oversight, extent and consequences, Stockholm: Stockholm University.

Borchorst, A. and Siim, B. (2002) 'The women-friendly welfare states revisited', NORA - Nordic Journal of Feminist and Gender Research, 10(2), 90-98.

Burns, A. and Iliffe, S. (2009) 'Dementia', BMJ, 338(7691), 405-409.

DAI (A Dementia Alliance International) (2016) The Human Rights of People Living with Dementia - from Rhetoric to Reality (A Dementia Alliance International publication to coincide with the adoption by Alzheimer's Disease International of a Human Rights based approach, and to coincide with Dementia Awareness Week UK 2016), 16 May (first edition).

Eloniemi-Sulkava, U., Sormunen, S. and Topo, P. (2008) 'Dementia on erityiskysymys', in Sormunen S. and Topo P. (eds.) Laadukkaat dementiapalvelut - Opas kunnille, Jyväskylä: Gummerus, 9-14.

Esping-Andersen, G. (1999) Social Foundations of Postindustrial Economies, Oxford: Oxford University Press.

Ferri, C.P., Prince, M., Brayne, C., Brodaty, H., Fratiglioni, L., Ganguli, M., Hall, K., Hasegawa, K., Hendrie, H., Huang, Y., Jorm, A., Mathers, C., Menezes, P.R., Rimmer, E. and Scazufa, M. (2005) 'Global prevalence of dementia: a Delphi consensus study', Lancet, 366, 2112-2117.

Flacks, S. (2012) 'Deviant Disabilities: The Exclusion of Drug and Alcohol Addiction from the Equality Act 2010', Social and Legal Studies, 21(3), 395-412.

Fratiglioni, L., Launer, L.J., Andersen, K., Breteler, M., Copeland, J.R., Dartigues, J., Lobo A., Martinez-Lage, J., Soininen, H. and Hofman, A. (2000) 'Incidence of dementia and major subtypes in Europe: A collaborative study of population-based cohorts', Neurology, 54 Supplement 5, 10-5. 
Gardner, R.C., Valcour, V. and Yaffe, K. (2013) 'Dementia in the oldest old: a multi-factorial and growing public health issue', Alzheimer's Research and Therapy 5, 27-38.

Gilliard, J., Means, R., Beattie, A. and Daker-White, G (2005) 'Dementia care in England and the social model of disability - Lessons and issues', Dementia - International Journal of Social Research and Practice, 4(4), 571-586.

Harding, R. (2017) 'Care and relationality: supported decision making under the UN CRPD' in Harding, R., Fletcher, R. \& Beasley, C. (eds.), ReValuating Care in Theory, Law and Policy. Cycles and Connections. London: Routledge.

HE 160/2012 vp Hallituksen esitys eduskunnalle laiksi ikääntyneen väestön toimintakyvyn tukemista sekä iäkkäiden sosiaali- ja terveyspalveluista ja laiksi terveydenhuoltolain $20 \S: n$ kumoamisesta [Governments proposal for an act on supporting the functional capacity of the older population and on social and health care services for older persons] available at: https://www.eduskunta.fi/FI/vaski/HallituksenEsitys/Documents/he 160+2012.pdf (accessed July 2017)

Herring, J. (2013). Caring and the Law. Oxford and Portland: Hart Publishing.

Hoppania, H-K. (2015) 'Care as a Site of Political Struggle', Publications of the Department of Political and Economic Studies 25, Helsinki: University of Helsinki.

Huttunen, H., Kekäläinen, R., Kurkela, T. and Vauramo, E. (2011) Visioita lähitulevaisuuden palvelujärjestelmästä. Loppuraportti ikääntyvän yhteiskunnan palvelurakennukset -projektista, Aalto University, available at: http://www.sotera.fi/pdf/Loppuraportti_small.pdf

Jönsson, L. and Wimo, A. (2009) 'The Cost of Dementia in Europe. A Review of the Evidence, and Methodological Considerations', Pharmaco Economics 27(5), 391-403.

Karsio, O. and Anttonen, A. (2013) 'Marketisation of eldercare in Finland: legal frames, outsourcing practices and the rapid growth of for-profit services', in Meagher, G. and Szebehely, M. (eds.) Marketisation in Nordic eldercare: a research report on legislation, oversight, extent and consequences, Stockholm: Stockholm University.

Kelly, F. and Innes, A. (2013) 'Human rights, citizenship and dementia care nursing', International Journal of Older People Nursing 8(1), 61-70.

Kehusmaa, S. (2014) Hoidon menoja hillitsemässä. Heikkokuntoisten kotona asuvien ikäihmisten palvelujen käyttö, omaishoito ja kuntoutus. Sosiaali- ja terveysturvan tutkimuksia 131, Helsinki: Kela. 
Kiander, J. (2001) Laman opetukset: Suomen 1990-luvun kriisin syyt ja seuraukset, Helsinki: Valtion taloudellinen tutkimuskeskus.

Li, N., Zhang, L., Du, W., Pang, L., Guo, C., Chen, G. and Zheng, X. (2015) "Prevalence of dementia-associated disability among Chinese older adults: results from a national sample survey", American Journal of Geriatric Psychiatry, 23(3), 320-325.

Mental Health Foundation (2015) Dementia, Rights, and the Social Model of Disability: A new direction for policy and practice? Policy Discussion Article, available at: https://www.mentalhealth.org.uk/sites/default/files/dementia-rights-policy-discussion.pdf

The Ministry of Social Affairs and Health (2014) Vanhuspalvelulaki - Vastauksia usein kysyttyihin kysymyksiin [Elderly Care Act - Answers to Frequently Asked Questions], available at: http://www.stm.fi/vireilla/lainsaadantohankkeet/sosiaali ja terveydenhuolto/ikaantyneet/use in_kysyttyja\#pitk\%C3\%A4aikainen\%20hoito (Accessed September 2015).

The Ministry of Social Affairs and Health (2016a) Palvelujen menot ja rahoitus [Service Expenditure and Financing], available at: http://stm.fi/talous-ja-toiminta/palvelujen-menotja-rahoitus

The Ministry of Social Affairs and Health (2016b) Kärkihanke. Kehitetään ikäihmisten kotihoitoa ja vahvistetaan kaikenikäisten omaishoitoa. Hankesuunnitelma [Lead Project. Developing the home care of the aged and strengthening the informal care of all age groups], available at: http://stm.fi/documents/1271139/1957330/IO_Hankesuunnitelma.pdf/644a357d-bee9-4682$\underline{83 f 4-c 7 e 2020 d 74 d 4}$

The Ministry of Social Affairs and Health 2017. Luonnos 17.5.2017. Hallituksen esitys eduskunnalle laeiksi vammaisuuden perusteella järjestettävistä erityispalveluista sekä sosiaalihuoltolain muuttamisesta [Draft 17.5.2017. Governments proposal for an act on special services provided on the basis of disability] available at http://stm.fi/lausuntopyynnot

Mittler, P. (2015) The UN Convention on the Rights of Persons with Disabilities: Implementing a Paradigm Shift. Journal of Policy and Practice in Intellectual Disabilities, 12(2), 79-89.

Mäki-Petäjä-Leinonen, A. (2013) Ikääntymisen ennakointi - vanhuuteen varautumisen keinot, Helsinki: Talentum,

Mäki-Petäjä-Leinonen A, Hoppania H-K and Nikumaa H (2015) Finnish Elderly Care Act - Did it Improve the Legal Rights of People with Dementia? Poster presentation in Alzheimer Europe conference in Ljubjana, September. 
Mäki-Petäjä-Leinonen, A. (2017) 'Protecting a Person with Dementia through Restrictions of Freedom? Notions of Autonomy in the Theory and Practice of Elderly care', in Griffiths, A., Mustasaari, S. and Mäki-Petäjä-Leinonen, A. (eds.) Subjectivity, Citizenship and Belonging in Law: Identities and Intersections, Abingdon: Routledge, 146-170.

Nikumaa, H. (2010) Muistisairas sosiaaliturvan asiakkaana: Master's thesis, Tampere University of Applied Sciences.

Nikumaa, H. (2013) Elämä ei pääty muistisairauden diagnoosiin, REPEAT Regular and Structured Support of Memory Patient, Research report, Muistiliiton julkaisusarja.

Nikumaa, H. and Ryynänen V. (2015a) Muistisairaiden ihmisten yhdenvertainen oikeus vammaispalveluihin. Osa 1 Kuljetuspalvelut, Memo 1/2015, 17-19.

Nikumaa, H. and Ryynänen V. (2015b) Muistisairaiden ihmisten yhdenvertainen oikeus vammaispalveluihin. Osa 2 Henkilökohtainen apu, Memo 2/2015,25-26.

Prince, M., Bryce, R., Albanese, E., Wimo, A., Ribeiro, W. and Ferri, C. P. (2013) 'The global prevalence of dementia: A systematic review and meta-analysis', Alzheimer's and Dementia, 9, 63-75.

PTK 84/2009 vp Täysistunnon pöytäkirja [minutes of the plenary session in parliament], available at: $\quad$ https://www.eduskunta.fi/FI/vaski/poytakirja/Documents/ptk 84+2009.pdf\#search=ptk $\% 2084 \% 20 \% 2 \mathrm{~F} \% 202009$

OECD (2013) A Good Life in Old Age Policy Brief. OECD/European Commission, available at: http://www.oecd.org/els/health-systems/PolicyBrief-Good-Life-in-Old-Age.pdf

Ridha, B. and Josephs, K. (2006) 'Young-Onset Dementia: A Practical Approach to Diagnosis', The Neurologist 12(1), 2-13.

Stewart, A., Niccolai, S. and Hoskyns, C. (2011) 'Disability Discrimination by Association: A Case of the Double Yes?', Social and Legal Studies 20(2), 173-190.

Taghizadeh Larsson, A. and Österholm, J.H. (2014) 'How are decisions on care services for people with dementia made and experienced? A systematic review and qualitative synthesis of recent empirical findings', International Psychogeriatrics 26(11), 1849-1862.

Tuori, K. and Kotkas, T. (2016) Sosiaalioikeus, Helsinki, TalentumPro.

Vaarama, M. and Noro, A. (2005) Vanhusten palvelut. Lääkärikirja Duodecim, available at: http://www.terveyskirjasto.fi/terveyskirjasto/tk.koti?p artikkeli=suo00058

Viramo, P. and Sulkava, R. (2015), 'Muistisairauksien epidemiologia', in Erkinjuntti, T., Remes, A., Rinne, J. and Soininen, H. (eds.), Muistisairaudet, Keuruu: Otava.

Wimo, A., Jonsson, L., Bond, J., Prince, M., and Winblad, B. (2013), 'The worldwide economic impact of dementia 2010', Alzheimers and Dementia, 9(1), 1-11. 
